\title{
Polityczne show jako nowoczesny przykład komunikowania politycznego. Narodziny telewizyjnych debat wyborczych w Wielkiej Brytanii
}

$\mathrm{D}$ ebaty wyborcze prowadzone podczas kampanii prezydenckich od dawna weszły w krajobraz europejskich kampanii politycznych. Obecnie, w każdych wyborach politycznych jest miejsce na szeroka, żywą prezentację poglądów przez konkurencyjne strony polityczne z zachowaniem klasycznych zasad teatru greckiego, czyli miejsca, czasu i akcji ${ }^{1}$.

Niezwykle interesującym jest, iż od niedawna debaty stały się częścią kampanii wyborczej w Wielkiej Brytanii, która uległa współczesnym trendom, nie będąc systemem prezydenckim.

Wybory do parlamentu są niezwykle ważnym wydarzeniem w systemie brytyjskim, na skutek przejęcia władzy przez partię dominującą. To właśnie tu rozpoczyna się marketing polityczny. Partie polityczne, w różnym zakresie korzystają z technik marketingu politycznego, adaptują różne jego formy, z mniejszym lub większym sukcesem, wszystkie jednak doskonale rozpoznają potrzeby rynku politycznego ${ }^{2}$.

Jedną z cech szczególnych brytyjskich partii politycznych jest sposób powoływania liderów partyjnych, których osobowość jest ogromnym atutem każdej partii. Najlepiej to widać w okresie kampanii wyborczej, trwającej niecałe trzy tygodnie, rozpoczynającej się na ogół w sposób niezapowiedziany. W takiej sytuacji jest poniekąd oczywiste, że walka między partiami staje się rywalizacją ich liderów, tym bardziej, że jej zwycięzca może dysponować takim zakresem władzy, jakiego nie posia-

1 W. Cwalina, A. Falkowski, Marketing polityczny. Perspektywa psychologiczna, Gdańsk 2005, s. 353.

2 J. Less-Marshment, The political marketing revolution. Transforming the government of the UK, Manchester 2004, s. 16. 
dają inni szefowie państw i rządów w krajach demokratycznych. Dlatego już sam wybór przywódcy w największych partiach jest bardzo ważnym wydarzeniem politycznym ${ }^{3}$. Partia Pracy i Partia Konserwatywna rywalizują w każdych wyborach, zatrudniają specjalistów marketingu politycznego, doradców oraz korzystają z pomocy wolontariuszy. Te dwie dominujące partie, zdobywają również większość uwagi mediów. W praktyce oznacza to jednak, że niemalże każdy aspekt z życia partii jest podawany do wiadomości publicznej, co ze zrozumiałych względów, bardzo często ma znaczący wpływ na decyzje wyborców ${ }^{4}$.

Podsumowując, jak większość systemów politycznych i Wielka Brytania przekształca się w coraz bardziej prezydencki ustrój. Media, kampania, dynamika partii i potrzeba punktu centralnego oraz chęć rozwoju rządu i jego administracji, wszystko to skoncentrowane jest na osobie premiera, który technicznie pełni funkcję prezydenta, nie korzystając jednak z tego tytułu.

Wielka Brytania, w porównaniu do Stanów Zjednoczonych i wielu krajów europejskich nie wykształciła tradycji debat politycznych pomiędzy kandydatami na wysokie stanowiska rządowe. Należy jednak zauważyć, że każdej kampanii wyborczej towarzyszyły wyzwania na taki pojedynek. Brytyjski Premier, Partia Pracy i Partia Konserwatywna są świadomi niebezpieczeństw, jakie wiążą się z uczestnictwem w debatach transmitowanych na żywo w publicznej telewizji ${ }^{5}$, stąd też widoczna niechęć do takich wystąpień. McNair jednak wyjaśnia, iż Brytyjczycy mają możliwość oglądania premiera i lidera opozycji przez większość dni w roku, kiedy to polemizują w Izbie Gmin czy też w trakcie programu „Czas na Pytania do Premiera” („Prime Minister's Question Time”) transmitowanego przez BBC oraz radiowego programu „Any Questions” („Jakieś Pytania”) ${ }^{6}$. W tych programach bezstronny prowadzący kieruje debatą pomiędzy czteroma lub pięcioma uczestnikami, zwykle podzielonymi na prawicę, lewicę i centrum. Publiczność bierze czynny udział poprzez zadawanie pytań uczestnikom, a sam prowadzący często przyjmuje rolę rozjemcy. Jak łatwo się domyśleć wyżej wspomniane formy debat są szczegółowo zaplanowane i kontrolowane, począwszy od wy-

3 A. Pułło, Ustroje państw wspótczesnych, Warszawa 2006, s. 59.

${ }^{4}$ Political marketing. A comparative perspective, red. D. L. Lilleker, J. Lee-Marshment, Manchester 2005, s. 16.

5 B. McNair, An Introduction to Political Communication, Londyn 2009, s. 123.

${ }^{6}$ B. McNair, Wprowadzenie do komunikowania politycznego, Poznań 1998, s. 134. 
boru członków publiczności, a skończywszy na pytaniach kierowanych do polityków - a wszystko to, aby konfrontacja przebiegała w miłej, przyjaznej, pokojowej atmosferze. Z czasem jednak tradycyjne show telewizyjne stało się nudne, a oczekiwania widzów stały się coraz większe. W międzyczasie w Ameryce rozwinął się nowy, bardzo kontrowersyjny trend prowadzenia talk-show, co miało wpływ na rozwój podobnych wzorców w Wielkiej Brytanii. Dało to początek nowym, bardziej żywiołowym, mniej przewidywalnym tak-show, a także zreformowało istniejące programy. W efekcie, czego publiczność mogła częściej i swobodniej zabierać głos i stała się aktywnym uczestnikiem debaty. Rola prowadzącego znacznie wzrosła, mógł on interweniować w imieniu publiczności bardziej agresywnie i spontanicznie. BBC i inne stacje telewizyjne ciągle szukają nowych rozwiązań na prezentację publicznych debat politycznych, które pełniłyby funkcję informacyjną, edukacyjną, a także rozrywkową ${ }^{7}$, a przy tym nie pozbawiały uczestników poczucia komfortu i kontroli.

Brytyjczycy, którym odebrano możliwości oglądania liderów politycznych rywalizujących w telewizyjnych debatach na żywo, nie byli jednak pozbawiani nadziei, iż takie starcie będzie miało miejsce. Jak już wcześniej wspomniano żarliwa dyskusja dotycząca debat towarzyszyła każdym wyborom powszechnym. „Żelazna Dama” Wielkiej Brytanii, Margaret Thatcher odmówiła uczestnictwa w debacie telewizyjnej w 1979, 1983 i 1987 r., obawiając się ewentualnej porażki ${ }^{8}$. W 1992 r. Neil Kinnock (Partia Pracy) zwrócił się z propozycją debaty telewizyjnej do ówczesnego premiera Johna Majora (Partia Konserwatywna), który odmówił udziału twierdząc, iż „Polityk, który spodziewa się przegranej, próbuje tego triku, polityk, który spodziewa się wygranej odpowiada nie" . Rok 1997 był niemalże idealnym momentem na negocjacje dotyczące debat telewizyjnych z udziałem liderów politycznych. Premier posiadał słabą pozycję, którą mógłby wzmocnić podczas takiego pojedynku. Jednakże i w tym przypadku, po długich negocjacjach, do których partie nie zasiadły przy wspólnym stole, nie doszło do porozumienia. Według specjalistów wina leżała po stronie obu partii, które nie były wystarczająco zaangażowane i nie poczyniły odpowiednich starań, aby doszło do spotkania, inni uważają, iż winę ponoszą stacje telewizyjne,

7 B. McNair, An Introduction..., op. cit., s. 76.

8 A. Mitchell, The Great British Exception..., op. cit., s. 110.

9 R. Holme, Third Party and Television Debates, w: Televised..., op. cit., s. 97. 
które również nie potrafiły osiagnąć porozumienia ${ }^{10}$. Z kolei Alistair Campbell, doradca Tony'ego Blaira stwierdził, iż debaty nie pełnią funkcji informacyjnej, a media skupione na spektaklu pomijają istotne aspekty polityczne ${ }^{11}$, dlatego też nie widział potrzeby pojedynku. Na tym etapie można również zaryzykować stwierdzenie, że brytyjskie partie wychodziły z założenia, iż dobrym sposobem na debatę jest jej brak. Robert MacNeil ${ }^{12}$ twierdzi, iż doświadczony doradca często musi odnosić się do sprawdzonych technik, aby trzymać swojego kandydata $\mathrm{z}$ dala od debat, które mogą zaszkodzić jego wizerunkowi. Autor cytuje Joe Napolitana, który przedstawia następujące rozwiązanie: „Gdybym pracował dla kandydata, który jest faworytem, oczywiście trzymałbym go z dala od debat telewizyjnych. Jednakże, nigdy oficjalnie nie odmówiłbym uczestnictwa w debacie. W przypadku propozycji debaty zawsze mów: «Tak, oczywiście. A może mój doradca spotka się z twoim o godzinie $16.00 \mathrm{w}$ czwartek, co Pan na to?». Następnie w umówiony czwartek o godzinie 15.55, dzwonisz do niego i mówisz: «Mamy dzisiaj prawdziwy kryzys, możemy to przenieść na sobotę?». W sobotę przekładasz to na następną środę... i tak do znudzenia"13. Jak wynika z powyższych rozważań decyzja o uczestnictwie w debacie wymaga myślenia strategicznego, głównie zorientowanego na kandydacie i jego pozytywnym wizerunku. Jednak w 2010 r., zaobserwować mogliśmy zupełnie inną sytuacje, wydawać by się mogło, że to liderzy polityczni dążyli do przeprowadzenia debat, po to, aby poprawić swój wizerunek, który znacznie ucierpiał w 2009 r. W podobnej sytuacji znalazło się wówczas większość brytyjskich partii, stąd nagła zmiana stanowisk w stosunku do telewizyjnych debat na żywo. Pragnęli oni dotrzeć do jak największej publiczności, aby odkupić swoje winy, i w ten sposób zachęcić ludzi do aktywnego udziału w życiu politycznym Wielkiej Brytanii.

10 Oferta dotyczyła dwóch, godzinnych debat, które miały być transmitowane przez BBC i ITV dwa tygodnie przed wyborami. Pozostałe stacje telewizyjne miałyby możliwość darmowej prezentacji owych debat. Forma spotkań byłaby identyczna, z prowadzącym Davidem Dimbleby w BBC i moderatorem Jonathanem Dimbleby w ITV. Debaty miały być transmitowane na żywo w czasie największej oglądalności w BBC1 i ITV.

11 S. Coleman, Televised Leaders' Debates Revisited. UK 2001 - A Debate Odyssey, „Hansard Society”, marzec 2001, s. 2.

12 R. MacNeil, The People Machine: The Influence of Television on American Politics, Nowy Jork 1968, s. 174-175.

13 The Past and Future of Presidential Debates, red. A. Ranney, Washington 1979, s. 11. 
Wszystko więc wskazywało na to, iż przed wyborami parlamentarnymi 2010 kandydaci na stanowisko premiera - liderzy trzech głównych partii politycznych (Gordon Brown - Partia Pracy, David Cameron - Partia Konserwatywna, Nick Clegg - Partia Liberalno-Demokratyczna), zaprezentują swoje umiejętności podczas debat telewizyjnych.

Potencjalni kandydaci na stanowisko premiera, nie brali wcześniej udziału w tego rodzaju konfrontacji, wszyscy jednak wyrazili zgodę na uczestnictwo w pierwszej, w historii Wielkiej Brytanii debacie wyborczej. D. Cameron stwierdził, iż debaty ożywią brytyjską demokrację i pomogą obywatelom znaleźć odpowiedź na nurtujące ich pytania ${ }^{14}$. G. Brown w swoich wypowiedziach skupił się na informacyjnej funkcji debat telewizyjnych, wskazując na tematykę debat, dotyczącą polityki gospodarczej, społecznej i zagranicznej ${ }^{15}$. Z kolei lider Partii Liberalno-Demokratycznej był przekonany, że po ciężkim roku ('expenses scandals') debaty moga pomóc w procesie odnowy aktywnego uczestnictwa obywateli brytyjskich w polityce. N. Clegg miał nadzieję, że otwarta, szczera i energiczna debata zachęci ludzi do głosowania ${ }^{16}$. Jak łatwo zauważyć, na tym etapie negocjacji liderzy polityczni zgadzali się, co do kwestii wzięcia udziału w debatach telewizyjnych oraz roli debat w komunikowaniu politycznym.

Przeciagające się negocjacje pomiędzy stacjami telewizyjnymi (BBC, ITV i Sky News) i partiami politycznymi zaowocowały 76 stronicowym porozumieniem, którego główne aspekty obejmowały następujące postanowienia:

- odbędą się trzy 90 minutowe spotkania poprzedzające wybory;

- każda z wyżej wspomnianych stacji telewizyjnych będzie odpowiedzialna za produkcję jednej debaty;

- uczestnikami debaty będą liderzy Partii Pracy, Partii Konserwatywnej oraz Partii Liberalno-Demokratycznej, którzy będą traktowani według takich samych zasad;

- stacje telewizyjne mają wyznaczyć osobę, która będzie monitorowała przebieg debaty, doradzała i współpracowała z producentem debaty, który będzie odpowiedzialny za równe traktowanie uczestników;

14 BBC News, Politics, Brown to face three televised election debates, http://news.bbc.co.uk/1/hi/uk_politics/8425280.stm, 15.12.2009 r.

15 BBC News, Europe, Brown: 'It would be right to debate', http://news.bbc.co.uk/1/hi/world/europe/8288921.stm, 15.12.2009 r.

16 BBC News, Politics, Brown to face three televised election debate, http://news.bbc.co.uk/1/hi/uk_politics/8425280.stm, 15.12.2009 r. 
- stacje telewizyjne muszą zachować taki sam format debat;

- następujące osoby będą prowadziły debaty: Alaistair Stewart, ITV; Adam Boulton, Sky; David Dimbleby, BBC;

- każdy z kandydatów będzie miał możliwość wygłoszenia wystąpienia początkowego, trwającego 1 minutę oraz wystąpienia końcowego trwającego 1 minutę i 30 sekund, odpowiedź na pytanie nie może być dłuższa niż 60 sekund, kandydat będzie także dysponował 1 minutą na to by odnieść do wypowiedzi kontrkandydatów;

- blisko dwustuosobowa widownia zostanie wyselekcjonowana w oparciu o następujące czynniki: płeć, wiek, narodowość, klasa społeczna, tak, aby zobrazować zróżnicowanie społeczeństwa;

- wybrani przedstawiciele widowni będą posiadali możliwość zadania, wcześniej przygotowanego i zatwierdzonego pytania uczestnikom debaty;

- moderator przedstawi liderów; będzie posiadał biurko/podium, i poruszał się $\mathrm{w}$ niewielkim polu, tak, aby nie tracił kontaktu $\mathrm{z}$ widownią i kandydatami;

- moderator ma prowadzić show, kontrolować czas, wyjaśniać nieścisłości, jego rolą jednak nie jest krytykowanie czy komentowanie wypowiedzi kandydatów;

- kandydaci będą stali przy podium, a ich usytuowanie będzie poprzedzone porozumieniem partii ${ }^{17}$;

- tematyka debat:

\begin{tabular}{|c|c|c|}
\hline $\begin{array}{c}\text { I debata } \\
\text { Polityka wewnętrzna }\end{array}$ & $\begin{array}{c}\text { II debata } \\
\text { Polityka zagraniczna }\end{array}$ & $\begin{array}{c}\text { III debata } \\
\text { Gospodarka }\end{array}$ \\
\hline Imigracja & Unia Europejska & Budżet \\
\hline Przestępczość & Zmiany klimatyczne & Podatki \\
\hline Reforma polityczna & Wizyta Papieża & System bankowy \\
\hline Edukacja & Reforma polityczna & Rozwój przemysłu \\
\hline Deficyt budżetowy & Emerytury & Politycy/imigracja \\
\hline Wojsko & Parlament & Polityka mieszkaniowa \\
\hline Służba Zdrowia & Imigracja & Zasiłki \\
\hline Emeryci i renciści & & Przyszłość młodego pokolenia \\
\hline
\end{tabular}

Źródło: M. Harrison, The X-Factor Election, w: D. Kavanagh, P. Cowley, The British General Election of 2010, Pargrave Macmillan 2010, s. 266.

17 M. Hook, A. Hitchins, Televising leaders or prime ministerial debates, Parliament and Constitution Centre, „Library House of Commons”, z dnia 11 marca 2010, s. $12-19$. 
Ostatecznie, posiadacze odbiorników telewizyjnych w Wielkiej Brytanii uzyskali możliwość obejrzenia liderów partii politycznych podczas pojedynku twarzą w twarz. W 2010 r. odbyły się trzy debaty wyborcze:

- I debatę przeprowadzono 15 kwietnia 2010 r. o godzinie 20.30 w Manchesterze, transmitowana i zorganizowana przez ITV;

- II debata miała miejsce 22 kwietnia 2010 r. o godzinie 20.00 w Bristolu, transmitowana i organizowana przez Sky News;

- III debata odbyła się 29 kwietnia 2010 r. o godzinie 20.30 w Birmingham, wyemitowana i zorganizowana przez BBC.

Pierwsza debata przyciagnęła średnio 9,4 mln widzów, zaczynając od 8,8 mln o godzinie 20.30 , a następnie utrzymując oglądalność na poziomie 9,3 mln o godzinie 21.45. Druga debata, transminowana przez Sky News, która nie była emitowana na żywo w żadnym z programów telewizji publicznej, uzyskała oglądalności równą 4,1 mln. Ostatnie „show” zostało obejrzane przez blisko 8,1 milionową publiczność ${ }^{18}$. Powyższe dane sytuują debaty wyborcze na tym samym poziomie oglądalności, co serial telewizyjny, „Coronation Street”, cieszący się w Wielkiej Brytanii ogromną popularnością ${ }^{19}$. Jak wynika z powyższych danych telewizyjne show w postaci debat politycznych okazało się prawdziwym hitem telewizyjnym. Pojedynki kandydatów spotkały się ze sporą aprobatą społeczną.

W przed dzień debaty Ipsos MORI przeprowadził badania, dotyczące najlepszych wystapień kandydatów na premiera. Uczestnicy poparli D. Camerona, uważając, że to on najlepiej wypadnie podczas debaty, uzyskał 53\% głosów, na kolejnym miejscu był G. Brown, z 20\% poparciem, a następnie N. Clegg z $12 \%{ }^{20}$. Rzeczywisty rezultat był jednak zupełnie inny niż się spodziewano.

G. Brown miał najtrudniej. Przyparty do muru, co chwilę był zmuszony bronić dorobku swojego rządu. Trzeba także pamiętać, że zaliczył

18 M. Harrison, The X-Factor Election, w: D. Kavanagh, P. Cowley, The British General Election of 2010, Pargrave Macmillan 2010, s. 266.

19 W każdy czwartek o godzinie 20.30 ITV1 transmituje kolejny odcinek popularnego serialu „Coronation Street” (na dzień dzisiejszy 26 V 2011 r., począwszy od roku 1960 wyemitowano ok. 7614 odcinków), którego średnia oglądalność wynosi ok $8 \mathrm{mln}$ widzów. Na podobnym poziomie znajdują się także seriale: „EastEnders” i „Doctor Who”. Źródło: Guardian, Election Debate TV Rating, http://www.guardian.co.uk/media/2010/apr/23election-debate-tv-ratings, 30.04.2010 r.

20 Britain Votes 2010, red. A. Geddes, J. Tonge, The Hansard Society 2010, S. 220 . 
pijarowską wpadkę, kiedy podczas spotkania z wyborcami, zapominając o wyłączeniu mikrofonu, nazwał „bigotką” jedną ze swoich zagorzałych zwolenniczek. Analizując jego „body language”, G. Brown, jawił się jako kandydat o nienajlepszej kondycji fizycznej, świadczyły o tym jego problemy z oddychaniem. Sprawiał wrażenie schorowanego i wyraźnie zmęczonego. Nie prezentował się także jako przyjacielski, uśmiechnięty, pełen wigoru kandydat, a raczej jako ktoś, kto przerażał swoim wyglądem i agresywnym zachowaniem ${ }^{21}$. Lider Partii Konserwatywnej wydał 66 tys. funtów, zatrudniając amerykańskich ekspertów od „body language", aby przekazano mu tajniki wizerunku Baracka Obamy ${ }^{22}$. Wkład amerykańskich specjalistów był wyraźnie widoczny w mowie ciała Camerona, szczególnie w gestach rąk i dłoni, charakterystycznych dla osoby prezydenta, do tej pory niespotykanych w kampaniach politycznych w Wielkiej Brytanii. Jego gestykulacja w połączeniu z opalenizną, dość szczupłą sylwetką i bardzo kontrolowanym zachowaniem sprawiały wrażenie nieco sztucznych i nienaturalnych ${ }^{23}$. Z kolei kandydat Liberalnej-Demokracji jawił się jako pełen energii, zrelaksowany, o nieco chłopięcym wyglądzie, niestety niczym nieprzypominający postawą potencjalnego lidera. Mimo to wystapienie Clegga (szczególnie w pierwszej debacie) okazało się prawdziwym hitem. Wszystkie jego odpowiedzi były kierowane w kierunku widowni i kamer, do zadających pytania zawsze zwracał się po imieniu (co w kolejnych debatach zostało, w mniej naturalny sposób kopiowane przez jego kontrkandydatów) ${ }^{24}$. Posiadał niezwykłą relację $\mathrm{z}$ widownią, był bardzo otwarty i naturalny. Ostatecznie po pierwszej debacie, ku niedowierzaniu wszyst-

21 Integration Training, UK Election Debate Candidates Body Language, http://integrationtraining.co.uk/blog/2010/04/uk-election-debate-candidates-body-language.html, 30.03.2011 r.

J. Groves, T. Cohen, David Cameron spent $£ 66000$ on TV coaching by Obama's body language expert during election campaign, „Daily Mail”, http://www.dailymail.co.uk/news/article-1335196/David-Cameron-spent-66-000-coaching-Obamas-body-language-expert.html, 30.03.2011 r.

M. Walsh, UK Election Debate - Candidates' Body Language, „Integration Training”, http://integrationtraining.co.uk/blog/2010/04/uk-election-debate-candidates-body-language.html, 30.03.2011 r.

24 N. Firth, Commentators come out in praise of Nick Clegg after live TV debate 'in which no one delivered the knockout blow, „Daily Mail”, http://www.dailymail.co.uk/news/election/article-1266426/Commentators-come-praise-Nick-Clegg-live-TV-debate-delivered-knockout-blow.html, 30.03.2011 r. 
kich Clegg uzyskał 61\% poparcie, na kolejnej pozycji uplasował się D. Cameron z $21 \%$ zaś na szarym końcu z 17\% poparciem znalazł się G. Brown.

W dalszym etapie rozważań warto wspomnieć, iż większość systemów politycznych sprzyja faworyzowaniu dwóch głównych kandydatów. Dzieje się tak dlatego, iż zachowanie kandydata trzeciej partii jest bardzo trudne do przewidzenia. Często nie postępuje on zgodnie z regułami, którymi kierują się pozostali kandydaci. Niejednokrotnie zawiera głos, aby wyrazić swój pogląd bądź wyolbrzymić problem, nie kierując się przy tym chęcią wygrania wyborów. Co więcej, obecność trzeciego kandydata może prowadzić do tego, iż dwóch pozostałych będzie podejmowało wspólne działania celem jego wyeliminowania. Takie postępowanie ma bezpośredni wpływ na popularność debat telewizyjnych, a także postrzeganie kandydatów przez widzów ${ }^{25}$. W przypadku, gdy trzeci kandydat ma szansę zdobycia dużej ilości głosów, bardzo rzadko dochodzi do debat, tak się jednak nie stało w Wielkiej Brytanii. Podsumowując N. Clegg, bardzo dobrze wykorzystał możliwość uczestnictwa w debacie liderów. Zrobił wszystko, aby zaprezentować swój program, przekonywał do swoich racji. Jego zadziwiający sukces zaowocował koalicją z Partią Konserwatywną.

Nie ma wątpliwości, że trzy debaty liderów partyjnych w Wielkiej Brytanii przyciagnęły do urn osoby, które po raz pierwszy mogły oddać swój głos w wyborach w 2010 r. Analiza Reuters Institute oparta na badaniach ankietowych YouGov potwierdziła, że osoby pomiędzy 18-24 rokiem życia wykazały szczególne zainteresowanie debatami. Więcej niż połowa badanych wskazała na wzrost zaangażowania w wyborach, zaś $75 \%$ respondentów przyznało, iż dzięki debatom zwiększyły swoją wiedzę na temat kandydatów i ich programów. Po wyborach 55\% młodych wyborców stwierdziło, że debaty liderów pomogły im w podjęciu decyzji, zaś $92 \%$ badanych przyznało, że dzieliło się swoimi poglądami na temat debat $\mathrm{z}$ otoczeniem. Jak widać debaty telewizyjne miały spory wpływ na wyborców, ze szczególnym wskazaniem na first-time voters. Sam fakt, iż cieszyły się one olbrzymim zainteresowaniem świadczy o wpływie debat na rozwój dyskursu publicznego - o debatach dużo się pisało i dyskutowało. Niewątpliwie stały się one niezapomnianym show

25 J. S. Trent, R. V. Friedenberg, Political Campaign Communication. Principles and Practices, Londyn 2003, s. 256. 
telewizyjnym. Prof. Steven Coleman uważa, że debaty powinny być kontynuowane w następnych wyborach parlamentarnych: „The door to televised debates in now well and truly open. It will be hard for politicians to close it" ${ }^{\prime 26}$.

Głównym celem tych wszystkich zabiegów jest zaproszenie wyborców do uczestnictwa w tym niebywałym spektaklu. Ważne jest także to, aby przyciagnąć uwagę, żeby następnego dnia w społeczeństwie o tym właśnie dyskutowano. Na pierwszym miejscu mają być obecne emocje, przeżycia czy wzruszenia, a nie programy wyborcze, na tym właśnie polega magia telewizyjnych debat wyborczych.

\section{Bibliografia}

\section{A. Publikacje}

Britain Votes 2010, red. A. Geddes, J. Tonge, The Hansard Society 2010.

Coleman S., Televised Leaders 'Debates Revisited. UK 2001 - A Debate Odyssey, Hansard Society, marzec 2001.

Cwalina W., Falkowski A., Marketing polityczny. Perspektywa psychologiczna, Gdańsk 2005.

Hook M., Hitchins A., Televising leaders or prime ministerial debates, Parliament and Constitution Centre, Library House of Commons, 11 marzec 2010.

Kavanagh D., Cowley P., The British General Election of 2010, Pargrave Macmillan 2010.

Leaders in the Living Room, The Prime Ministerial Debates of 2010: Evidence, Evaluation and Some Recommendations, red. S. Coleman, Oxford 2011.

Less-Marshment J., The political marketing revolution. Transforming the government of the UK, Manchester 2004.

MacNeil R., The People Machine: The Influence of Television on American Politics, New York 1968.

McNair B., An Introduction to Political Communication, London 2009.

McNair B., Wprowadzenie do komunikowania politycznego, Poznań 1998.

Political marketing. A comparative perspective, red. D. L. Lilleker, J. Lee-Marshment, Manchester 2005.

Pułło A., Ustroje państw wspótczesnych, Warszawa 2006.

26 Leaders in the Living Room, The Prime Ministerial Debates of 2010: Evidence, Evaluation and Some Recommendations, red. S. Coleman, Oxford 2011, s. 35-37. 
The Past and Future of Presidential Debates, red. A. Ranney, Washington 1979.

Trent J. S., Friedenberg R. V., Political Campaign Communication. Principles and Practices, Londyn 2003.

\title{
B. Internet
}

www.dailymail.co.uk

www.guardian.co.uk

www.integrationtraining.co.uk

www.news.bbc.co.uk

www.reuters.com

\section{Political spectacle as an example of modern political communication. The birth of televised election debates in the UK}

\begin{abstract}
Summary
Three debates involving the leaders of the main political parties in the UK attracted first-time voters in the 2010 elections. The analysis of the Reuters Institute, based on YouGov's questionnaires, confirmed that the 18-24 age group had shown particular interest in the debates. After the elections, $55 \%$ of the young electorate declared that the leaders' debates had helped them to make up their minds, whereas $92 \%$ admitted having exchanged opinions in their circles after the debates. Television debates have thus been shown to have a considerable influence on voters and in particular on first-time voters. The very fact that the debates enjoyed such enormous audience interest demonstrates the influence they have on the development of public discourse; political debates have been written about and discussed extensively. They have also undoubtedly become an unforgettable TV spectacle.
\end{abstract}


